\title{
Venous and Lung Thromboembolism in the Context of Lung Cancer: Clinical Manifestations, Risk Factors and Prognosis
}

\author{
Tromboembolismo Venoso e Pulmonar no Contexto \\ da Neoplasia Pulmonar: Manifestações Clínicas, \\ Fatores de Risco e Prognóstico
}

Rosana MAIA $\rrbracket^{1}$, Inês NEVES ${ }^{2}$, António MORAIS ${ }^{3}$, Henrique QUEIROGA ${ }^{3}$

Acta Med Port 2019 Oct;32(10):647-653 - https://doi.org/10.20344/amp.10260

\section{ABSTRACT}

Introduction: The relationship between cancer and thromboembolic events has been known for a long time. Lung and venous thromboembolism are frequent complications of lung cancer and its treatment, being a great cause of morbidity and mortality. We pretend to establish the relationship between lung and venous thromboembolism and lung cancer, describe patient characteristics and analyze the impact in the survival and prognosis.

Material and Methods: It was a retrospective study. All research subjects were selected from lung cancer patients with a newly diagnosed lung and venous thromboembolism event admitted to Hospital S. João, between January 2008 and December 2013 and were followed until December 2014. Statistical analysis was performed with SPSS.

Results: From the search, we obtained 113 patients. The majority was male, smokers or ex-smokers, and adenocarcinoma was the most frequent histologic type, being diagnosed mostly in advanced stages. We noticed that the median time between lung cancer diagnosis and lung venous thromboembolism was 2.9 months. In 24 patients $(21.4 \%)$, the lung cancer diagnosis occurred after the lung and venous thromboembolism event and in 86 patients $(76.8 \%)$, it occurred before the event. After a median follow up of 1.4 months, $107(94.7 \%)$ patients died, $1(0.9 \%)$ was lost to follow-up and $5(4.4 \%)$ were still alive. The median survival rate was 1.5 months.

Discussion: The diagnosis of lung and venous thromboembolism in patients with lung cancer is associated with bad prognosis. It occurs most frequently in patients with advanced disease, in the first months after lung cancer diagnosis and after beginning chemotherapy. Conclusion: Disease progression is an independent predictor with negative impact in overall survival.

Keywords: Lung Neoplasms; Pulmonary Embolism; Venous Thromboembolism

\section{RESUMO}

Introdução: A relação entre as neoplasias e os eventos tromboembólicos é uma realidade já conhecida. O tromboembolismo pulmonar e venoso são complicações frequentes das neoplasias e do seu tratamento. Pretende-se estabelecer a relação entre o tromboembolismo pulmonar e venoso e a neoplasia pulmonar, descrever as suas características clínicas e analisar o seu impacto na sobrevida e prognóstico.

Material e Métodos: Este estudo é retrospetivo. Foram selecionados doentes com neoplasia pulmonar, diagnosticados com tromboembolismo pulmonar e venoso no Hospital de S. João entre janeiro de 2008 e dezembro de 2013, e acompanhados até dezembro de 2014. A análise estatística foi realizada utilizando o SPSS.

Resultados: Da pesquisa efetuada, foram obtidos 113 doentes. A maioria eram homens, fumadores ou ex-fumadores, e o adenocarcinoma foi o tipo histológico mais frequentemente encontrado, diagnosticado maioritariamente em estádios avançados. A mediana de tempo entre o diagnóstico de neoplasia pulmonar e tromboembolismo pulmonar e venoso foi de 2,9 meses. Em 24 doentes (21,4\%), o diagnóstico de neoplasia pulmonar ocorreu depois do tromboembolismo pulmonar e venoso e em 86 doentes (76,8\%) antes do evento. Após uma mediana de follow-up de 1,4 meses, 107 (94,7\%) dos doentes faleceram, 1 (0,9\%) deixou de ser seguido e 5 (4,4\%) permaneceram vivos no fim do estudo. A mediana da taxa de sobrevivência foi de 1,5 meses.

Discussão: O diagnóstico de tromboembolismo pulmonar e venoso nos doentes com neoplasia pulmonar está associado a mau prognóstico. Ocorre mais frequentemente em doentes com doença avançada, nos primeiros meses depois do diagnóstico e do início da quimioterapia.

Conclusão: A progressão da doença demonstrarou ser preditor independente com impacto negativo na sobrevida global.

Palavras-chave: Embolia Pulmonar; Neoplasias Pulmonares; Tromboembolismo Venoso

\section{INTRODUCTION}

The relationship between cancer and thromboembolic events has been known for a long time. ${ }^{1}$

Lung thromboembolism and venous thromboembolism (VTE), which includes deep vein thrombosis (DVT) and pulmonary embolism (PE), are frequent complications of lung cancer and its treatment, especially in the advanced stages of disease. DVT is the occlusion of a blood vessel in any region of the body, but it is found more often in the lower limbs. PE is an occlusion of one or more pulmonary vessels which can be life-threatening. ${ }^{2,3}$

The pro-thrombotic state results from the activation of hemostasis, which promotes the induction of pro-coagulant activity and cancer cell migration, involving platelets.

\footnotetext{
1. Departamento de Medicina Interna. Unidade Local de Saúde do Alto Minho. Hospital de Santa Luzia. Viana do Castelo. Portugal.

2. Serviço de Pneumologia. Hospital Padre Américo. Matosinhos. Portugal.

3. Serviço de Pneumologia. Hospital de S. João. Porto. Portugal.

$\triangle$ Autor correspondente: Rosana Maia. rosana.8.maia@gmail.com

Recebido: 28 de janeiro de 2018 - Aceite: 29 de abril de 2019 | Copyright $\odot$ Ordem dos Médicos 2019
} 
According to a new cell-based model of coagulation, coagulation occurs in platelets or other cell surfaces that expose tissue factor (TF). In the end, those mechanisms can lead to tumor growth, angiogenesis and to the development of metastases. ${ }^{1,3,4}$ The malignancies with higher risk of VTE have hematologic, gastrointestinal and lung origin. ${ }^{1}$

The incidence of VTE in lung cancer patients is $4 \%-15 \%$ and the mortality rate is higher in comparison with patients who have not experienced a VTE event. ${ }^{5}$

In a large cohort of lung cancer patients, some risk factors were identified, like male gender, advanced stage of disease, adenocarcinoma, and co-morbidities such as heart failure, atrial fibrillation and cerebrovascular disease..$^{6,7}$

The hypercoagulable state that is characteristic of lung cancer patients is usually asymptomatic. However, in some cases, it can manifest as a low grade disseminated intravascular coagulation or VTE, which represents a serious manifestation of this state. That is why changes in a coagulation test might be the only finding in asymptomatic patients..$^{3,8}$

The aim of this study is to examine the association between VTE and lung cancer, describe patient characteristics and analyze the impact of these events in the survival and prognosis of lung cancer patients.

\section{MATERIAL AND METHODS}

\section{Study design and study population}

This is a retrospective uncontrolled study. All research subjects were selected from lung cancer patients with newly diagnosed VTE event admitted to Hospital S. João (HSJ) between January 2008 and December 2013 and were followed until December 2014. To achieve this, we requested a search of all malignant neoplasms of the bronchus or lung (ICD-9-CM codes '162.2x', '162.3x', '162.4x', '162.5x', '162.8x', '162.9x') from the hospital registry system in that period, which returned 2630 patients. We then searched for patients who also had a VTE episode, resulting in 113 patients.

The inclusion criteria were diagnosis of primary lung cancer, known histology, date of diagnosis, VTE symptoms, including deep vein thrombosis (ICD-9-CM codes '451.0x - 451.2', '451.8x - 451.9x', '453.0x - 453.4x', '453.6x', '453.8x - 453.9x') or pulmonary embolism (ICD-9-CM code '415.1x'), between 2008 and 2013.

The exclusion criteria were absence of date of diagnosis and unknown histology.

This information was collected from each patient's clinical chart, using SClinico Software (SClinico Hospitalar, SPMS - Health Ministry Shared Services). Permission for data collection and analysis was obtained from the ethics committee of HSJ. Our study was performed in accordance with the Declaration of Helsinki.

\section{Clinical data}

For each patient, clinical data included: (1) patient's basic information, such as gender, and age; (2) significant comorbidities such as overweigh, arterial hypertension, pulmonary disease, previous thromboembolism, renal disease, dyslipidemia, peripheral arterial disease, ischemic heart disease, congestive heart failure, cerebrovascular disease, diabetes mellitus, peripheral venous disease; (3) smoking history; (4) histology, date of diagnosis, stage at the time of diagnosis, presence of metastases; (5) type of treatment, such as chemotherapy, radiotherapy or surgery; (6) presence of risk factors, such as recent surgery, presence of central venous catheter, trauma; (7) type of VTE, date of the episode, origin, disease progression at the event date, symptoms, diagnostic method, D-dimers, treatment, complications; (8) date of death, date of last follow-up.

ECOG Performance Status, according to the Eastern Cooperative Oncology Group, was used to classify patients' functional performance: $0-5 .^{9}$

Tumor histology was classified as non-small cell lung cancer (NSCLC), small cell lung cancer (SCLC) and others. Furthermore, the NSCLC was sub-classified as adenocarcinoma, squamous cell carcinoma and large cell neuroendocrine carcinoma.

The stage of each case was classified as I (IA, IB), II (IIA, IIB), III (IIIA, IIIB), IV, according to the TNM system. For analysis purposes, disease stage was categorized into two groups: early (Stage I and II) and advanced stage (III and IV).

Chemotherapy in lung cancer usually includes a combination of platinum derivatives with gemcitabine, paclitaxel, vinorelbine, etoposide, or pemetrexed. Nevertheless, EGFR inhibitors, like gefitinib and erlotinib, and angiogenesis inhibitors, like bevacizumab, can also be used as a firstline treatment. ${ }^{7}$ As mentioned before, it has been reported that chemotherapy has some influence in the occurrence of VTE episodes, which is why we also include the type of treatment of each patient in our database.

Crizotinib, cerotinib and alectinib (ALK inhibitors) and immunotherapy (nivolumab and pembrolizumab) can also be used as first-line treatment. However, our database refers to the period between 2008 and 2013, when those therapies had not been approved yet. ${ }^{10}$

VTE was diagnosed based on several methods including angio-computed tomography (CT), thoracic CT, echocardiogram, Doppler ultrasound and abdominal CT. Two types of CT scanners were used: 16 slice and 64 slice.

In order to better understand the association between lung cancer and venous thromboembolism (VTE) and the possible predictors of overall survival, we also analyzed D-dimer levels which were obtained in the HSJ laboratory. To measure D-dimer levels, peripheral blood was collected from the cubital vein and then analyzed with STA Liatest D-DI. All the blood samples were processed according to the manufacturer's instructions. At our hospital, the standard cut off level of $0.5 \mu \mathrm{g} / \mathrm{mL}$ was used to distinguish high and normal results.

\section{Statistical methods}

Statistical analysis was performed with IBM SPSS 22.0 software package (IBM Corp. Released 2013. IBM SPSS Statistics for Windows, Version 22.0. Armonk, NY: IBM Corp.) 
Continuous variables were presented as means and standard deviation or median and percentile 25 (p25) and percentile 75 (p75), and categorical variables as absolute and relative percentages. Overall survival was defined as

Table 1 - Baseline patient characteristics

\begin{tabular}{|c|c|c|}
\hline Characteristics & & Patients $(n=113)$ \\
\hline Gender & $\begin{array}{l}\text { Male } \\
\text { Female }\end{array}$ & $\begin{array}{l}91(80.5) \\
22(19.5)\end{array}$ \\
\hline Age, mean, in years ( $p 25-p 75)$ & & $66(59-74)$ \\
\hline Age Groups & $\begin{array}{l}\leq 50 \\
51 \text { a } 65 \\
\geq 66\end{array}$ & $\begin{array}{c}7(6.2) \\
42(37.2) \\
64(56.6)\end{array}$ \\
\hline $\begin{array}{l}\text { Co-morbidities } \\
\text { Arterial hypertension } \\
\text { Pulmonary disease } \\
\text { Dyslipidemia } \\
\text { Diabetes mellitus } \\
\text { Ischemic heart disease } \\
\text { Congestive heart failure } \\
\text { Peripheral venous disease } \\
\text { Overweight } \\
\text { Cerebrovascular disease } \\
\text { Previous VTE } \\
\text { Chronic renal disease } \\
\text { Peripheral arterial disease }\end{array}$ & & $\begin{array}{l}77(68.1) \\
39(34.5) \\
23(20.4) \\
21(18.6) \\
18(15.9) \\
10(8.8) \\
7(6.2) \\
7(6.2) \\
4(3.5) \\
4(3.5) \\
3(2.7) \\
3(2.7) \\
2(1.8)\end{array}$ \\
\hline Smoking at lung cancer diagnosis & $\begin{array}{l}\text { Current smoker } \\
\text { Ex-smoker } \\
\text { Never smoker }\end{array}$ & $\begin{array}{l}48(43.6) \\
37(33.6) \\
25(22.7)\end{array}$ \\
\hline Lung cancer histology & $\begin{array}{l}\text { Adenocarcinoma } \\
\text { Squamous cell carcinoma } \\
\text { SCLC } \\
\text { NSCLC, unspecified } \\
\text { Large cell neuroendocrine carcinoma }\end{array}$ & $\begin{array}{c}79(70.5) \\
13(11.6) \\
9(8 \%) \\
9(8) \\
2(1.8)\end{array}$ \\
\hline Stage at the time of lung cancer diagnosis & $\begin{array}{l}\text { IA } \\
\text { IB } \\
\text { IIA } \\
\text { IIB } \\
\text { IIIA } \\
\text { IIIB } \\
\text { IV }\end{array}$ & $\begin{array}{c}0(0) \\
0(0) \\
0(0) \\
1(0.9) \\
3(2.7) \\
29(26.4) \\
77(70)\end{array}$ \\
\hline $\begin{array}{l}\text { Metastasis at the time of lung cancer diagnosis } \\
\text { Bone } \\
\text { Lung } \\
\text { Pleural } \\
\text { Cerebral } \\
\text { Others }\end{array}$ & & $\begin{array}{l}77(70) \\
43(38.1) \\
27(23.9) \\
25(22.1) \\
15(13.3) \\
33(29.2)\end{array}$ \\
\hline Anticancer treatment & $\begin{array}{l}\text { Chemotherapy } \\
\text { Biological therapy } \\
\text { Radiotherapy } \\
\text { Surgery } \\
\text { Chemotherapy at the time of VTE event }\end{array}$ & $\begin{aligned} 87 & (77.7) \\
16 & (19.8) \\
43 & (38.4) \\
7 & (6.3) \\
47 & (53.4)\end{aligned}$ \\
\hline Risk factors for VTE & $\begin{array}{l}\text { Recent surgery } \\
\text { Co-morbidities } \\
\text { Thrombophilia } \\
\text { Central venous catheter } \\
\text { Trauma }\end{array}$ & $\begin{aligned} & (2.7) \\
77 & (68.1) \\
1 & (0.9) \\
1 & (0.9) \\
1 & (0.9)\end{aligned}$ \\
\hline Symptoms and signs at VTE diagnosis & & $100(88.5)$ \\
\hline ECOG & $\begin{array}{l}0 \\
1 \\
2 \\
3 \\
4\end{array}$ & $\begin{array}{c}6(5.3) \\
29(25.7) \\
12(10.6) \\
44(38.9) \\
22(19.5)\end{array}$ \\
\hline Disease progression & $\begin{array}{l}\text { No } \\
\text { Yes }\end{array}$ & $\begin{array}{l}26(23.4) \\
85(76.6)\end{array}$ \\
\hline
\end{tabular}


the time between the beginning of VTE and the death from any cause or last contact. Patients still alive were censored at the last follow-up date. The Kaplan-Meyer method was performed to calculate the overall survival, and univariate and multivariable Cox proportional regression analyses were used to establish the predictors of overall survival in lung cancer patients. In multivariable analysis, variables that showed significance at $p<0.20$ in univariate analysis were included. The results are expressed as hazard ratios with $95 \% \mathrm{Cl}$. A $p$-value $<0.05$ was used as the criterion for statistical significance in the multivariable model.

\section{RESULTS}

\section{Patient characteristics}

In a population of 2630 patients with the diagnosis of lung cancer, $113(4.30 \%)$ were also diagnosed with VTE between 2008 and 2013.

The baseline characteristics of the 113 patients are shown in Table 1.

The average age at time of VTE was 66 years (with a standard deviation of 10). The majority of patients were male $(80.5 \%)$ and smokers or ex-smokers $(77.2 \%)$. Adenocarcinoma was the most frequent histology $(70.5 \%)$, followed by Squamous cell carcinoma (11.6\%), SCLC (8\%), unspecified NSCLC (8\%) and large cell neuroendocrine carcinoma (1.8\%). As expected, we also verified that lung cancer was mostly diagnosed in advanced stages of the disease $-70 \%$ in stage IV and $26.4 \%$ in stage IIIB.

As shown in Table 1, patients received different anticancer treatments: $77.7 \%$ chemotherapy, $19.8 \%$ biological therapy, $38.4 \%$ radiotherapy and finally $6.3 \%$ underwent surgery.

\section{Prevalence and clinical characteristics of VTE}

In this group of 113 patients, $24(21.2 \%)$ experienced an episode of DVT, 76 (67.3\%) an episode of PE, 12 (10.6\%) DVT and PE and 1 (0.9\%) suffered another type of event.

As previously mentioned, not all of these events were symptomatic. In our study, 100 patients (88.5\%) were

Table 2 - Clinical characteristics of VTE

\begin{tabular}{lc}
\hline Characteristics & $\begin{array}{c}\text { Patients } \\
\text { (n = 113) }\end{array}$ \\
\hline Signs and symptoms & \\
Dyspnea & $70(78.7)$ \\
Cough & $40(35.4)$ \\
Hemoptysis & $10(8.8)$ \\
Thoracic pain & $2(23)$ \\
DVT symptoms & $29(25.7)$ \\
Syncope & $5(4.4)$ \\
Atrial fibrillation (AF) & $8(7.1)$ \\
Tachyarrhythmia & $47(41.6)$ \\
Hemodynamic instability & $10(8.8)$ \\
Edema of the lower limbs & $25(22.5)$ \\
Hypoxemia & $67(59.3)$ \\
Time of lung cancer diagnosis and VTE event & \\
Before VTE event & $86(76.8)$ \\
At the time of VTE event & $2(1.8)$ \\
After VTE event & $24(21.4)$ \\
Median, in months (p25 - p75) & $2.9(-8.0)$ \\
\hline
\end{tabular}

Numbers in parentheses refer to $n(\%)$, unless otherwise specified symptomatic at the time of the event and $13(11.5 \%)$ were asymptomatic (Table 2).

Most of the patients had a VTE event in the ambulatory setting (86.7\%). Only 15 patients $(13.3 \%)$ had a VTE event while hospitalized.

VTE was diagnosed by different imaging techniques (angio-CT, thoracic CT, abdominal CT, and Doppler ultrasound). The most frequently used technique was angio-CT (56.4\%), followed by thoracic CT (27.3\%). Doppler ultrasound was essentially used for DVT diagnosis (13.6\%). Despite the available techniques, VTE was not confirmed in $1.8 \%$ of patients. In some patients (48.7\%), we measured D-dimer levels, which proved to be elevated in most of them (94.6\%).

By the event date, most patients had disease progression $(76.2 \%)$, accompanied by the presence of metastasis and local advanced disease.

We noticed that the median time between lung cancer diagnosis and VTE event was 2.9 months. In 24 patients (21.4\%), lung cancer diagnosis occurred after a VTE event and in 86 patients $(76.8 \%)$, it occurred before a VTE event.

We also noticed that most VTE events occurred after the beginning of chemotherapy (53.4\%), with an average of 6 months interval.

\section{Management of VTE in patients with lung cancer}

At the time of the event, only $5.3 \%$ of patients were under anticoagulant therapy [LMWH $(0.9 \%)$, warfarin $(3.5 \%)$ and acenocoumarol $(0.9 \%)$ ] (Table 3 ). In order to deal with VTE, healthcare professionals administered anticoagulant therapy, which includes warfarin, enoxaparin, dalteparin, unfractionated heparin and acenocoumarol.

The administration of anticoagulant therapy poses some risks, such as hemorrhagic complications, which were found in 12 patients $(10.6 \%)$ [epistaxis $(8 \%)$, hemoptysis $(0.8 \%)$, hemopericardium $(0.8 \%)$ ]. Despite the use of anticoagulant therapy, in four patients $(3.5 \%)$ there was recurrence of a VTE event.

Knowing that all our patients were hospitalized during these events, we also analyzed the outcomes at the time of discharge. Most patients had clinical improvement and were discharged (54.9\%). However, 41 patients $(36.3 \%)$ died during hospitalization and 10 patients (8.8\%) were discharged without clinical improvement.

\section{Survival and predict factors}

After a median follow up of 1.4 months (range, 0 to 33), $107(94.7 \%)$ patients died, $1(0.9 \%)$ patient was lost to

Table 3 - Anticoagulant therapy chosen at the time of the event

\begin{tabular}{lc}
\hline Anticoagulant therapy & $\begin{array}{c}\text { Patients } \\
\text { (n = 113) }\end{array}$ \\
\hline None & $5(4.5)$ \\
Warfarin & $38(33.9)$ \\
Enoxaparin & $60(53.6)$ \\
Dalteparin & $1(0.9)$ \\
Unfractionated heparin & $7(6.3)$ \\
Acenocoumarol & $1(0.9)$ \\
\hline
\end{tabular}

Numbers in parentheses refer to $\mathrm{n}(\%)$, unless otherwise specified 
Table 4 - Predictive factors of overall survival

\begin{tabular}{|c|c|c|c|c|}
\hline & Univariate Analysis & & Multivariable Analysis & \\
\hline Baseline Characteristics & Hazard Ratio $(95 \%$ Cl) & $p$-value & Hazard Ratio $(95 \% \mathrm{CI})$ & $p$-value \\
\hline $\begin{array}{l}\text { Gender } \\
\text { Female } \\
\text { Male }\end{array}$ & $\begin{array}{c}1 \\
1.007(0.624-1.626)\end{array}$ & 0.976 & & \\
\hline $\begin{array}{l}\text { Age groups } \\
\quad \leq 50 \\
51 \text { a } 65 \\
\geq 66\end{array}$ & $\begin{array}{c}1.423(0.703-2.879) \\
1.018(0.678-1.527) \\
1\end{array}$ & $\begin{array}{l}0.327 \\
0.932\end{array}$ & & \\
\hline $\begin{array}{l}\text { Disease progression } \\
\text { No } \\
\text { Yes }\end{array}$ & $\begin{array}{c}1 \\
1.975(1.234-3.151)\end{array}$ & 0.004 & $1.831(1.101-3.044)$ & 0.020 \\
\hline $\begin{array}{c}\text { ECOG } \\
0 \\
1 \\
2 \\
3 \\
4\end{array}$ & $\begin{array}{c}1 \\
1.639(0.573-4.691) \\
1.877(0.596-5.908) \\
3.646(1.301-10.219) \\
6.479(2.188-19.183)\end{array}$ & $\begin{array}{l}0.357 \\
0.282 \\
0.014 \\
0.001\end{array}$ & $\begin{array}{c}1.064(0.363-3.117) \\
1.172(0.365-3.756) \\
2.048(0.713-5.883) \\
3.982(1.334-11.886)\end{array}$ & $\begin{array}{l}0.910 \\
0.792 \\
0.183 \\
0.013\end{array}$ \\
\hline $\begin{array}{l}\text { Histology } \\
\text { Others } \\
\text { Adenocarcinoma }\end{array}$ & $\begin{array}{c}1 \\
1.461(0.946-2.256)\end{array}$ & 0.087 & $1.359(0.861-2.143)$ & 0.188 \\
\hline $\begin{array}{l}\text { Stage } \\
\text { Early } \\
\text { Advanced }\end{array}$ & $\begin{array}{c}1 \\
1.703(0.824-3.516)\end{array}$ & 0.150 & $1.478(0.702-3.109)$ & 0.304 \\
\hline $\begin{array}{l}\text { Metastasis } \\
\text { No } \\
\text { Yes }\end{array}$ & $1.269(0.840-1.918)$ & 0.258 & & \\
\hline $\begin{array}{l}\text { Chemotherapy } \\
\text { No } \\
\text { Yes }\end{array}$ & $\begin{array}{c}1 \\
1.223(0.790-1.892)\end{array}$ & 0.367 & & \\
\hline
\end{tabular}

follow-up and $5(4.4 \%)$ were still alive at the end of the study time of VTE event, histological type, stage of lung cancer, (Table 4). The median survival rate was 1.5 months.

We also tried to analyze some possible predictive facand treatment with chemotherapy.

In univariate analysis, disease progression and ECOG tors of OS, for instance ECOG, disease progression by the (3 and 4) were associated with overall survival. In turn,

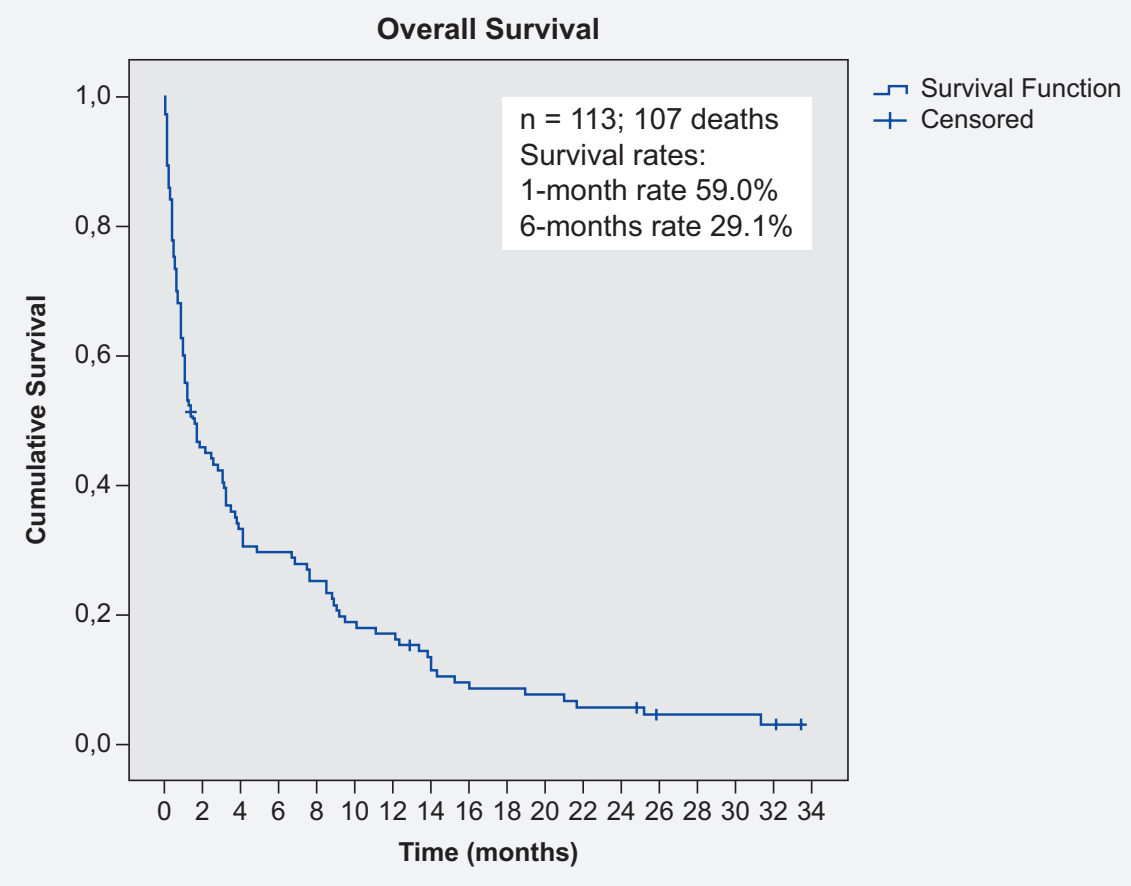

Figure 1 - Overall survival 
gender, age group, advanced stage, metastasis and chemotherapy were not found to be significant. The variables concerning progression, ECOG, histology and stage were included in the multivariable model since they generated a $p<0.2$ in univariate analysis.

After multivariable analysis, only progression and $\mathrm{ECOG}=4$ were associated with overall survival. Progression was associated with worse overall survival, presenting an increased hazard ratio $(\mathrm{HR})$ of death $(\mathrm{HR}=1.831 ; 95 \% \mathrm{Cl}$ : $1.101-3.044)$. In addition, patients with ECOG $=4$ had an increased $\mathrm{HR}$ of death $(\mathrm{HR}=3.982 ; 95 \% \mathrm{Cl}: 1.334-11.886)$ compared with patients with ECOG $=0$ (Fig. 1).

\section{DISCUSSION}

In a large cohort of lung cancer patients, the prevalence of VTE was $4.3 \%$. As shown in Table 1, it was found more frequently in males $(80.5 \%)$, with a median age of 66 years. Most of them had co-morbidities (68.1\%) such as arterial hypertension, pulmonary disease, dyslipidemia, diabetes mellitus and others, and $77.2 \%$ were current-smokers or ex-smokers. The median survival rate was 1.5 months, and in 86 patients $(76.8 \%)$ lung cancer diagnosis occurred before a VTE event. After multivariable analysis, only progression and ECOG $=4$ were associated with overall survival.

Cancer patients are a heterogeneous population, so the VTE incidence will fluctuate between the different groups and will be influenced by various factors. ${ }^{1}$ These factors can be divided into patient-related factors (advanced age, poor performance status - ECOG — with a prolonged immobility, prior history of thrombotic events and the presence of co-morbidities), tumor-related factors (type and stage), treatment-related factors (surgery, chemotherapy and new therapies) and potential biologic parameters. ${ }^{1,2,11-13}$

VTE can represent the earliest manifestation of an occult malignancy, leading to the diagnosis of lung cancer, as seen in our cohort (21.4\%). Most of our patients were symptomatic at the time of a VTE event (88.5\%). However, with the increasing use of routine staging and follow-up imaging, clinically unsuspected pulmonary embolism (PE) is commonly detected $(11.5 \%) .{ }^{14}$

Adenocarcinoma is the most common histological type of lung cancer and it also seems to be associated with a higher occurrence of VTE events $(70.5 \%$ in our study). It may be explained by the presence of mucus produced by this histological type, which may lead to secretion of pro coagulation factors, platelet activation and to microthrombi formation in capillary circulation. ${ }^{7,15}$ However, we cannot affirm that the higher occurrence of VTE in lung cancer patients may be due to the higher prevalence of this histological type alone.

Our patients underwent different types of treatment, and most of them $(77.7 \%)$ were receiving chemotherapy. As mentioned above, cancer by itself is strongly associated with a pro-thrombotic state. However, chemotherapy can lead to endothelial damage,$^{1}$ increasing the risk of developing a VTE event, especially in the first $3-6$ months of treatment, as we can observe in our results with an average of six months. . $^{3,12,16}$

For the diagnosis of these events, the most frequently used technique was angio-CT (56.4\%) and, when measured, D-dimer levels proved to be elevated in most cases (94.6\%).

D-dimer is a degradation product of cross-linked fibrin and high levels reflect the increased activation of hemostasis and fibrinolysis. ${ }^{17}$ It can be important for the diagnosis of suspected PE. Nevertheless, in hospitalized patients, this elevation can be caused by co-morbidities, which limits its applicability. ${ }^{18}$ It can help to exclude VTE due to its high negative predictive value. However, it is only by combining D-dimer results with imaging techniques such as CT that VTE diagnosis can be made. ${ }^{13}$

In a recent study, the American Society of Clinical Oncology (ASCO) guidelines leave to the clinician the decision to implement anticoagulant prophylaxis in designated patients with solid tumors and high risk of thrombosis after the clinician assessment of the risk of mortality and associated morbidity. ${ }^{3}$

LMWH was the preferred option for treatment and prophylaxis in our patients (54.5\%).

As it has been shown in previous studies, some of our patients experienced hemorrhagic complications (10.6\%), which influence their morbidity and mortality. Moreover, despite the use of anticoagulation, the risk of VTE recurrence is higher in comparison with noncancerous patients. ${ }^{1}$

Nowadays, many risk factors for VTE are being studied. In our study, only disease progression and ECOG (4 in comparison to 0 ) were proven to be a predictor for overall survival. Therefore, further investigation is needed to clarify the relationship between VTE and lung cancer and its predictors.

There are several inflammatory biomarkers related to thrombotic events. Tissue factor, which is an initiator of the activation of hemostasis, has proven to be constitutively expressed and related to a hypercoagulable state. Neutrophils are responsible for the degradation of tissue factor pathway inhibitor. ${ }^{19}$ Knowing that, one possible predictor of VTE events is an elevated leukocyte count prior to the initiation of chemotherapy. Leukocytosis might be responsible and linked to inflammation, lung cancer aggressiveness or disease progression. And in the end, all these factors contribute to the increased risk of thrombosis. ${ }^{11,20}$

The overproduction of pro coagulation factors such as TF also promotes the production of thrombin. Therefore, an elevated platelet count may also be used as a predictor of VTE. ${ }^{7,11}$

Kadlec et al also found that other procoagulant factors are associated with an increased risk of VTE such as lupus anticoagulant, anticardiolipin antibodies to factor VIII, IL-6 and TNF-alfa. ${ }^{7}$ In a recent study, it was demonstrated that the high neutrophil-lymphocyte ratio (NLR) is associated with a lower VTE resolution rate and to some resistance to anticoagulant therapy. ${ }^{19}$

VTE can be considered as a negative predictor of survival in lung cancer patients, complicating cancer treatment. 
It carries a significantly poorer prognosis. ${ }^{2,7,11}$ However, the benefits of VTE prophylaxis remain unknown. ${ }^{15}$

This study presents some limitations. It does not include all the patients diagnosed with lung cancer that experienced a VTE event. The clinical information of some patients was not available and some patients were followed in another hospital after lung cancer diagnosis. During data collection some coding errors were detected, which did not allow the precision of VTE and lung cancer diagnosis that we intended at the beginning. There were probably many patients with asymptomatic VTE that were not detected. There are new predictors and recently discovered risk factors that we did not include in our analysis (neutrophil-lymphocyte ratio, tumor markers like CEA, and others).

\section{CONCLUSION}

The diagnosis of venous thromboembolism (VTE) in patients with lung cancer carries a poor prognosis. It occurs more frequently in patients with advanced disease, in the first months after lung cancer diagnosis and in the first months after beginning chemotherapy.

\section{REFERENCES}

1. Kyriazi V, Theodoulou E. Assessing the risk and prognosis of thrombotic complications in cancer patients. Arch Pathol Lab Med. 2013;137:1286-95.

2. Yang Y, Zhou Z, Niu XM, Li ZM, Chen ZW, Jian H, et al. Clinical analysis of postoperative venous thromboembolism risk factors in lung cancer patients. J Surg Oncol. 2012;106:736-41.

3. Roselli M, Riondino S, Mariotti S, La Farina F, Ferroni P, Guadagni F. Clinical models and biochemical predictors of VTE in lung cancer. Cancer Metastasis Rev. 2014;33:771-89.

4. Zhang PP, Sun JW, Wang XY, Liu XM, Li K. Preoperative plasma $D$-dimer levels predict survival in patients with operable non-small cell lung cancer independently of venous thromboembolism. Eur J Surg Oncol. 2013;39:951-6.

5. Connolly GC, Menapace L, Safadjou S, Francis CW, Khorana AA. Prevalence and clinical significance of incidental and clinically suspected venous thromboembolism in lung cancer patients. Clin Lung Cancer. 2013;14:713-8.

6. Connolly GC, Dalal M, Lin J, Khorana AA. Incidence and predictors of venous thromboembolism (VTE) among ambulatory patients with lung cancer. Lung Cancer. 2012;78:253-8.

7. Kadlec B, Skrickova J, Merta Z, Dusek L, Jarkovsky J. The incidence and predictors of thromboembolic events in patients with lung cancer. ScientificWorldJournal. 2014;2014:125706.

8. Tas F, Kilic L, Serilmez M, Keskin S, Sen F, Duranyildiz D. Clinical and prognostic significance of coagulation assays in lung cancer. Respir Med. 2013;107:451-7.

9. Oken MM, Creech RH, Tormey DC, Horton J, Davis TE, McFadden ET, et al., Toxicity and response criteria of the Eastern Cooperative Oncology Group. Am J Clin Oncol.1982;5: 649-55.

10. Ettinger DS, Wood DE, Akerley W, Bazhenova LA, Borghaei H, Camidge DR, et al. NCCN Guidelines Insights: Non-Small Cell Lung Cancer, Version 4.2016. J Natl Compr Canc Netw. 2016;14:255-64.

11. Wang Z, Yan HH, Yang JJ, Wang BC, Chen HJ, Zhou Q, et al. Venous
Disease progression and ECOG have been found to be independent predictors with negative impact in overall survival.

\section{PROTECTION OF HUMANS AND ANIMALS}

The authors declare that the procedures were followed according to the regulations established by the Clinical Research and Ethics Committee and to the Helsinki Declaration of the World Medical Association.

\section{DATA CONFIDENTIALITY}

The authors declare having followed the protocols in use at their working center regarding patients' data publication.

\section{CONFLICTS OF INTEREST}

All authors report no conflict of interest.

\section{FUNDING SOURCES}

This research received no specific grant from any funding agency in the public, commercial, or not-for-profit sectors.

thromboembolism risk factors in Chinese non-small cell lung cancer patients. Support Care Cancer. 2015;23:635-41.

12. Huang $\mathrm{H}$, Korn JR, Mallick R, Friedman M, Nichols $C$, Menzin J. Incidence of venous thromboembolism among chemotherapy-treated patients with lung cancer and its association with mortality: a retrospective database study. J Thromb Thrombolysis. 2012;34:446-56.

13. Corrales-Rodriguez L, Blais N. Lung cancer associated venous thromboembolic disease: a comprehensive review. Lung Cancer. 2012;75:1-8.

14. Shinagare AB, Okajima $Y$, Oxnard GR, Dipiro PJ, Johnson BE, Hatabu $\mathrm{H}$, et al. Unsuspected pulmonary embolism in lung cancer patients: comparison of clinical characteristics and outcome with suspected pulmonary embolism. Lung Cancer. 2012;78:161-6.

15. Malgor RD, Bilfinger TV, Labropoulos N. A systematic review of pulmonary embolism in patients with lung cancer. Ann Thorac Surg. 2012;94:311-6.

16. Ferroni P, Martini F, Portarena I, Massimiani G, Riondino S, La Farina $F$, et al. Novel high-sensitive D-dimer determination predicts chemotherapy-associated venous thromboembolism in intermediate risk lung cancer patients. Clin Lung Cancer. 2012;13: 482-7.

17. Ay C, Dunkler D, Pirker R, Thaler J, Quehenberger P, Wagner O, et al. High D-dimer levels are associated with poor prognosis in cancer patients. Haematologica. 2012;97:1158-64.

18. Fijałkowska A, Wiatr E, Kurzyna M, Kuca P, Burakowski J, Kober J, et al. Normal D-dimer concentration in hospitalized patients with lung diseases. Pneumonol Alergol Pol. 2012;80:101-8.

19. Go SI, Lee A, Lee US, Choi HJ, Kang MH, Kang JH, et al. Clinical significance of the neutrophil-lymphocyte ratio in venous thromboembolism patients with lung cancer. Lung Cancer. 2014;84:79-85.

20. Connolly GC, Khorana AA, Kuderer NM, Culakova E, Francis CW, Lyman GH. Leukocytosis, thrombosis and early mortality in cancer patients initiating chemotherapy. Thromb Res. 2010;126:113-8. 